\title{
GEOMYTHOLOGICAL APPROACH OF ASOPOS RIVER
} (AEGINA, GREECE)

\author{
Mariolakos I. ${ }^{1}$ and Theocharis D. ${ }^{1}$ \\ ${ }^{1}$ National and Kapodistrian University of Athens, Faculty of Geology and Geoenvironment, \\ Department of Dynamic Tectonic Applied Geology, GR-15784 Athens, Greece, \\ mariolakos@geol.uoa.gr,dtheocharis@geol.uoa.gr
}

\begin{abstract}
In Greek Mythology rivers are, with some exceptions, Gods and they were "born" by the Titans, Oceanus and Tethys. The River Gods are also considered to have given birth to some Islands. Amongst them Asopos River has the most important position as he is considered to have given birth to Aegina, Salamis, Euboe and some other islands as well.

The myth of Asopos River is remarkable because it is a typical case where the physical-geological evolution allows us to explain the myth, and at the same time, the myth lets us to give an explanation about the diachronic route of Asopos riverbed, especially during the crucial period between 18,000 to 6,000 BP.

The area, known as Saronic Gulf today, used to partly be land, including a great lake, the Epidaurus Paleolake, until 13,000 BP. Asopos River, nowadays known as "Rema tis Skotinis", is located on Aegina island.
\end{abstract}

In this paper we are trying to investigate whether Asopos River was flowing either into the Epidaurus Paleolake or into the Saronic Paleogulf.

Key words: geomythology, Asopos, Saronic Gulf, Aegina, paleogeography.

\section{Introduction}

According to Theogony, which was composed by the great poet Hesiod, rivers were "born" by the couple of Titans known as Oceanus and Tethys. These Titans gave birth to over three thousands Rivers and to an equal number of Oceanides (Fig. 1). After all, according to the same poet in the genealogy of the Greek Theogony, rivers belong to the 4th generation of Gods. The fact that they belong to the same generation of Poseidon and Zeus, who are sons of two others Titans Cronus and Rhea, it is also remarkable.

Rivers are the only physical geographical systems that have been deified. It is also remarkable the fact that neither the Mountains nor Pontus, the other big physical geographical system, which belong to the 2 nd generation, had been deified.

Rivers have defined the cultural process of human societies, especially those who lived in the Aegean and Peri-Aegean regions, but also those who lived in European and African regions as well. This is the reason why the Greek Mythology also refers to rivers, which are located beyond the Greek territory like the Nile, Istrus (Danube), Eridanus (Po), Vorysthenis (Dnieper), etc. 


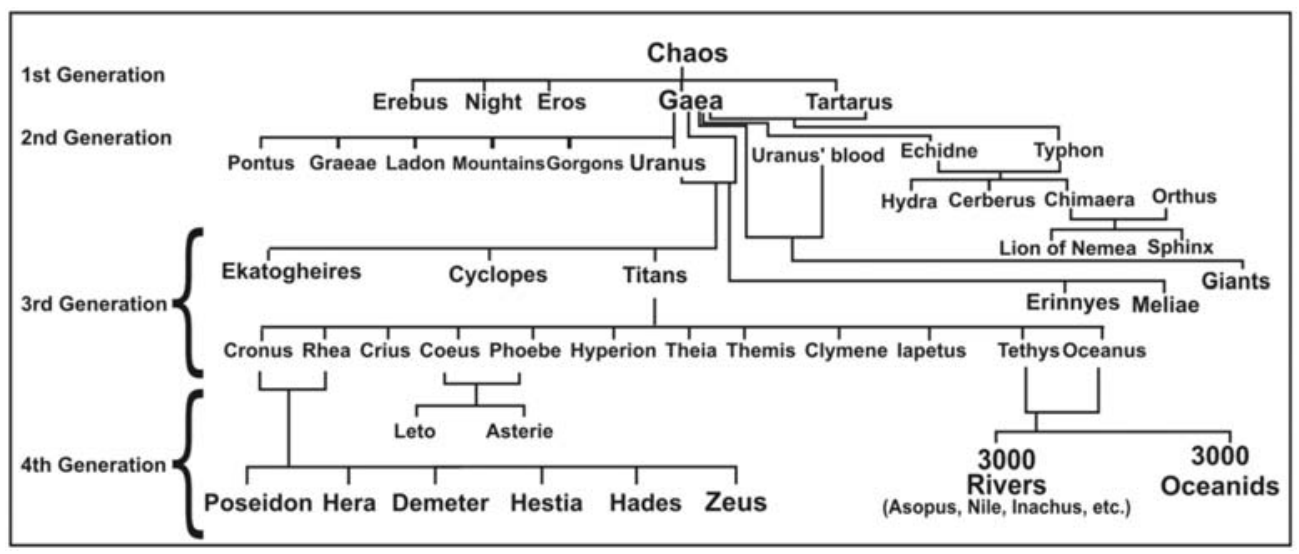

Fig. 1: Genealogical chart of Gods and Heroes.

The River-Gods are usually considered to be the progenitors of many islands. Asopos is considered to have been the progenitor of Aegina, Salamis, Euboea and some other islands, whereas Acheloos is considered to have been the progenitor of the Echinades islands, Nile of Egypt, etc. In other occasions, the genealogy of a river, which is located in a specific area, is connected with kings, who gave their name to some islands. For example, Meander is considered to be the progenitor of Samos Island.

We think that the reasons of that interrelationship must be connected with the vertical displacement of the sea level, probably because they had accepted that rivers water should be responsible for this.

Nowadays, of course, we know that the global sea level rising is attributed to the melt of the glaciers. In other words with movements which are well known as climatic-eustatic. In the prehistoric era, the inhabitants of the Aegean and Peri-Aegean regions were certainly unaware of the relationship between the increase of the global mean annual atmospheric temperature, the melt of the glaciers and the sea level rising.

\section{The Rivers as physical geographical system}

Almost all rivers are distinguished in two parts, upstream and downstream. The beginning of the upstream creation, in many cases, is usually very old and it is preceded the appearance of Homo.

Therefore all physical geological processes that are connected with the upstream of various rivers cannot influence the diachronic cultural development of Homo sapiens and as a result the inhabitants of the Aegean and Peri-Aegean region, as the Homo sapiens had not yet existed. So all the physical geological processes, related to the upstream of rivers are not expected to appear in Greek Mythology. Of course, we cannot exclude the possibility that somewhere, a myth could have been related with the upstream since in certain areas alterations have influenced the cultural development of inhabitants, who have settled along a river terrace or generally in an area around it. This is expected since the upstream of the rivers doesn't remain completely unchangeable. This mainly concerns to the rivers of the Greek territory because in major drainage networks, outside Greece, the environment is significantly different and much more complicated.

Therefore most references in Greek Mythology, but also in the mythology of other nations, must be associated with those parts of the rivers which have evolved from the appearance of humans and on- 
wards. In the case of rivers downstream, when flew across the alluvial fans and deltas areas, the physical geological evolution is complicated and it becomes even more complicated because of the sea level fluctuations due to climate changes. It is known that many references in Greek Mythology concerning the above facts have been unfortunately ignored, obviously because they have been considered as imagination of the Greeks.

The delta areas have determined the cultural development of humans. This concerns all deltas all over the world and especially the large ones. In the Aegean and Peri-Aegean area, although the rivers are comparative smaller, they have effected the development of the ancient Greek civilization. This is the basic reason why rivers are often reported in Greek Mythology. As a result, anyone could hardly claim that there is a river, which is not reported in Greek Mythology. Therefore the detailed study of the rivers" delta presents not only geomythological interest but also scientific and "historic" interest, because under certain circumstances they allow us to "date" some physical geological processes, and in addition we can raise two issues:

(i) Greek Mythology is not an imaginary fiction, it is not a fairy-tail, but it is a story that describes physical geological events of a past period, which is so old that it is very difficult for us to understand it. The last is absolutely excused because today's physical geological status is completely different from that of the period before $6,000 \mathrm{BP}$, and

(ii) how old the Greek Mythology is.

How can someone, who is not familiar with all these impressive changes of the land surface relief in the wider Aegean and Peri-Aegean region, for example, realize that Aegina didn't exist as an island approximately 14,000 years BP or that Salamis became an island just 4,000 years BP (Mariolakos \& Theocharis, 2003).

\section{The Asopos River and the myth}

Asopos is a very small stream, which is located on Aegina Island and discharges south of the city of Aegina. Its ancient name is almost unknown to the inhabitants of Aegina as it is called today "Rema tis Skotinis".

The name Asopos has been given to other rivers as well. One of them is located in Attica and discharges into the southern Evoikos Gulf, another one crosses part of Fthiotis prefecture, near to Thermopyles, and discharges into the northern Evoikos Gulf. So both rivers have been considered as the progenitors of Euboea Island. Another river with the same name is located in Korinthia prefecture and discharges into the Korinthian Gulf.

It is remarkable though how such a currently insignificant stream has been considered as the progenitor of two of the biggest islands of the Saronic Gulf, namely Aegina and Salamis, including also some other islands such as Euboea and others. Could it simply be imagination or it could include fragments of truth regarding the paleogeographical evolution of Aegina and Salamis and consequently the paleogeographical evolution of the Saronic Gulf in general?

From a geomythological point of view, the myth that considers Asopos as the father of Aegina and Salamis is noteworthy, because it's a typical case where the physical geological evolution of the wider area helps the myth to be explained and at the same time the myth helps a correct explanation to be given about the diachronic route of the Asopos river.

A land with a relative great lake, the Epidaurus Paleolake, was developed until around 14,000 years $\mathrm{BP}$ in the area that today is partly occupied by the western Saronic Gulf (Mariolakos \& Theocharis, 

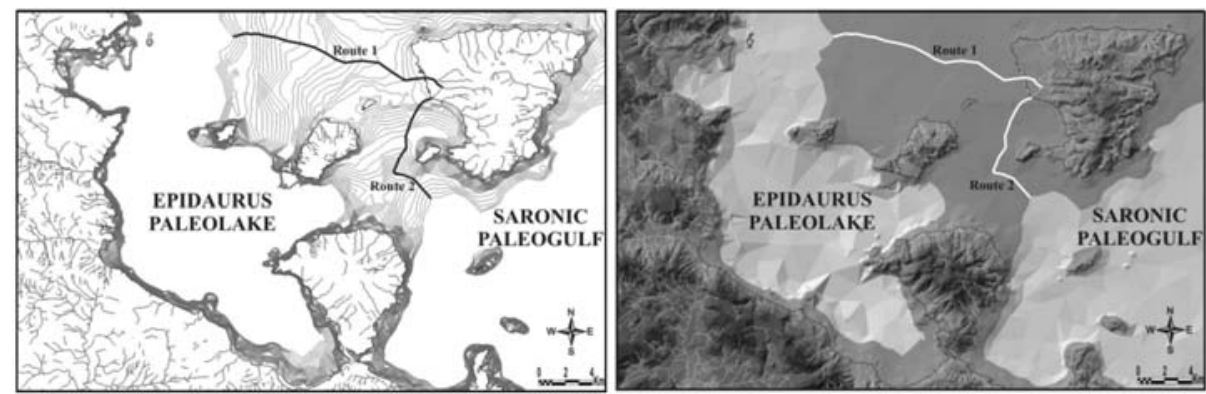

Fig. 2: The possible routes of Asopos river to Epidaurus Paleolake (Route 1) and Saronic Paleogulf (Route 2) is represented: a) on isobaths map of the present day Saronic Gulf, contour interval $5 \mathrm{~m}$, from 0 to -125 meters, b) digital terrain model of the paleorelief which corresponds to $18000 \mathrm{BP}$.

2003). That means that the bigger and smaller islands, which are seen today, hadn't been shaped by that time. The main branch of Asopos, which is known today as "Rema tis Skotinis", begins from the interior of Aegina Island draining the slopes of the mountains Platyvouni, Trikorfi and Vouno Dendrou.

In the case of Asopos, a big question is raised, concerning especially the period that the Saronic Gulf hadn't yet been shaped. Was the water of Asopos River discharged into the Epidaurus Paleolake (Route 1, Fig. 2) or into the Saronic Paleogulf (Route 2, Fig. 2)? The answer in this question is very important because, if the physical geological - paleogeomorphological analysis proves that paleo-Asopos discharged into the sea and not into the Epidaurus Paleolake then the view that Asopos is considered to be the father of Aegina is enhanced because humans, who were living in the Upper Palaeolithic era probably connected the rising of the sea level with the rivers' overflow.

In order to provide an answer to this question a comparative analysis should be carried out including i) the alluvial fans of the river and ii) the coastline displacement due to the climatic-eustatic movements after 18,000 BP. So let's follow step by step the paleogeographical evolution of Asopos route and its alluvial fans (Fig 3,5) based mainly: i) on the alluvial fans that have been deposited

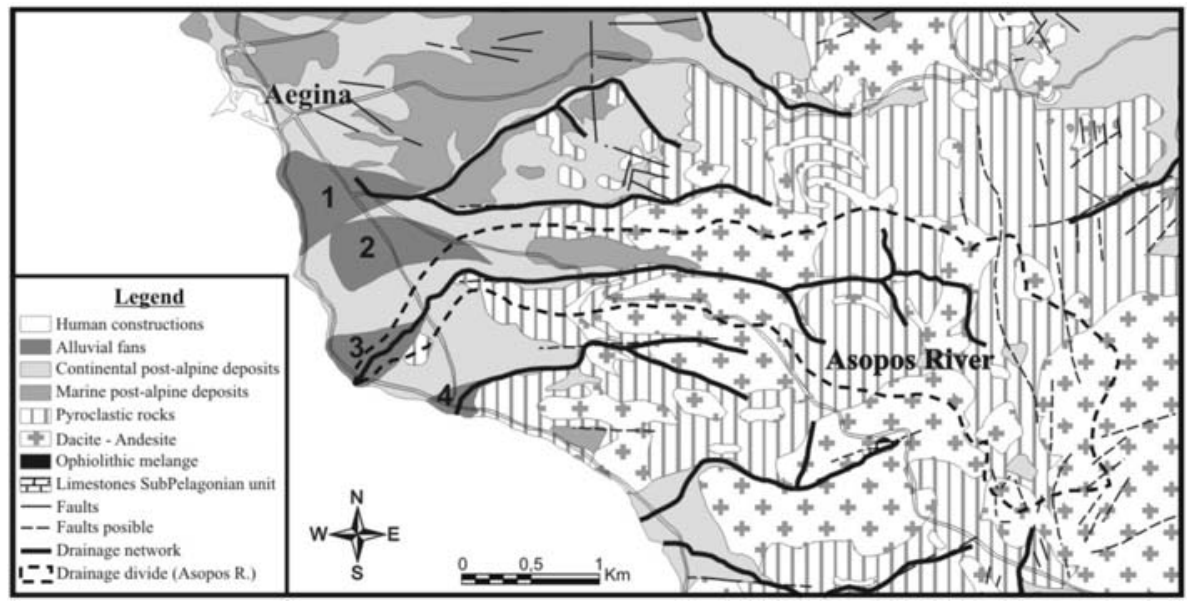

Fig. 3: Geological map modified from Dietrich et al 1991. It is shown, also, the catchments area of the Asopos River and the four alluvial fans of the wider area. 

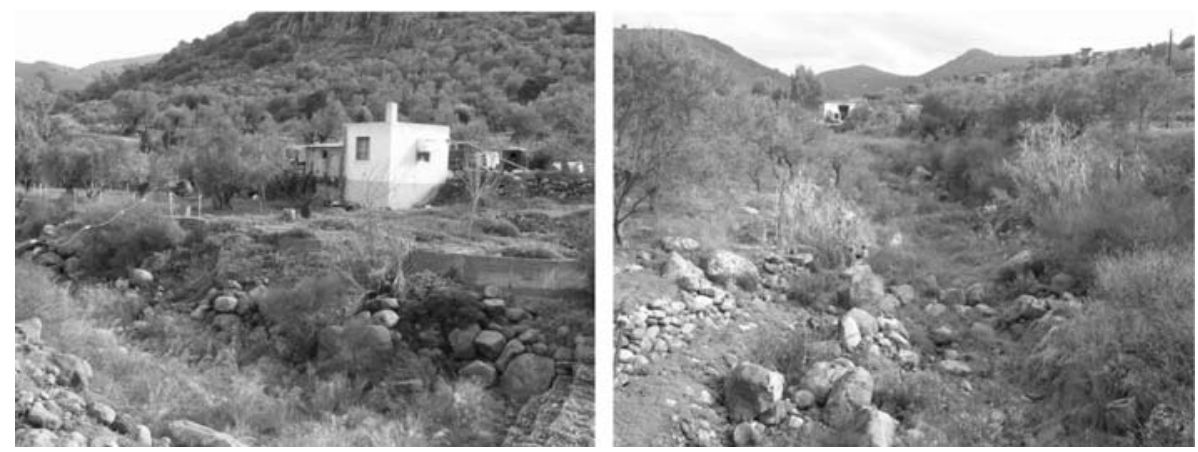

Fig. 4: Boulders in the riverbed Asopos indication of the transport capacity of the river in an earlier period.

after the stabilization of the sea level, that happened after the climate optimum of the Holocene $(6,000-4,000$ years BP), ii) on the shape of isobaths and iii) on the qualitative morphological correlation with the present shape of the alluvial fans.

Currently, Asopos River, who's its drainage basin extends to the western part of the island, flows initially to the west and then turns around abruptly to the southwest, developing along its banks an alluvial fun, which today is eroded by the river.

In the area around the modern banks of Asopos River, appear four alluvial fans (fig. 3). From the north to the south an alluvial fun appears, which is partly crossed by the anonymous stream (fan 1, Fig. 3). In modern times, the anonymous stream cannot reach the sea. This shows that the specific alluvial fan is not active now and furthermore the stream, which has washed away the material, must be inactive under today's climatic conditions.

Another alluvial fan (fan 2, Fig. 3) is developed southern than the previous one, which seems to be an abandoned fan of Asopos. Exactly on the top of the second fan, Asopos turns abruptly to the southwest, abandoning the specific fan and creating another younger one (fan 3, Fig. 3), which its top is located further west, of the present street, which runs across all these three alluvial fans.

Further south, another alluvial fun exists (fan 4, Fig. 3), which is drained by another stream that is much smaller than Asopos and the anonymous one, and flows northern. It also creates an abrupt angular bending in two sites.

The general overview shows that Asopos flowed northwestern of its today's flow until a certain time. We have a sudden shifting of the riverbed. Consequently this alluvial fun (fan 2) must be older and must have been abandoned for some reason. The most probable reason is the active tectonism of the area. In addition this area is volcanically active consequently a volcanic eruption could have created a change like this in the past.

Based on the above mentioned it is possible that Asopos River could have been formerly joined with the anonymous one, which flows further north, if we take into account the fact that the anonymous river does not reach the sea today. The question is whether a stream of that size can create such an extended alluvial fan.

These four alluvial fans have been definitely created after the climate optimum of the Holocene, and thus after the final formation of the Saronic Gulf. Consequently any shape and flow direction of Asopos can not characterize Asopos River as the progenitor of Aegina and Salamis, since the 


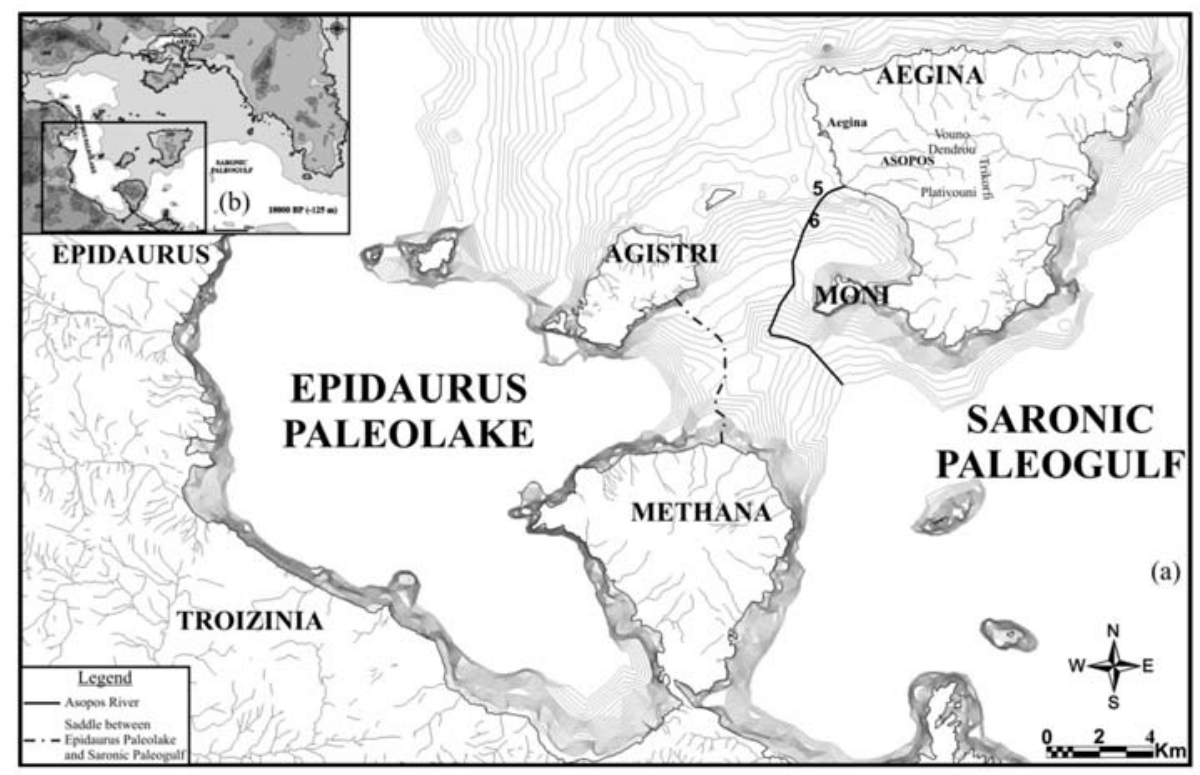

Fig. 5: (a) Offshore alluvial fans distinguished by the shape of isobaths. The alluvial fan 5 bounded by the contour of minus 10 meters and the alluvial fan 6 of the contours between minus 35 and 45 meters. (b) Paleo-geographical map of Saronic Gulf 18,000 BP (after Mariolakos \& Theocharis 2003).

older islands inhabitants, that is before the period of the climatic optimum of Holocene, couldn't have witnessed the final formation of their coastlines.

It would be therefore interesting to observe up to the point where we can, what might have been the possible route of Asopos River in the period of time between 18,000 BP and 6,000 BP that is the period within which drastic climatic-eustatic movements occurred. For this purpose the topographic map of the bottom of the Saronic Gulf was drawn down (Fig. 5), using G.I.S. since earlier a digitization of all the bathymetric points was done from the maps of the Hellenic Military Geographical Service (HMGS).

In Fig. 5 a part of the map that includes Aegina, Methana, Troizinia and the Epidaurus Paleolake is depicted. Our aim is to define, up to the point that it is possible, a route of Asopos River during the last 18,000 years. For this reason we have chosen the contour line of minus 125 meters, as it is considered that the sea level that period must have been 120-130 meters below the present due to the climatic-eustatic movements (Lambeck 1996).

From the shape of the isobaths on the map of Fig. 5 it comes out that the contour of minus 10 meters creates a morphological lobe, which we consider that corresponds to a submarine alluvial fan (fan 5), created by the sediments of Asopos in a past era. From the depth that the alluvial fan is developed we consider that it corresponds to the time space between 7,000-8,000 BP. This conclusion is enforced by the fact that the morphological lobe is geographically located on the extension of the onshore fans and especially in front of the fans 2 and 3 (Fig. 3). As we mentioned above the alluvial fan 2 is older then the modern fan 3.

The former riverbed of the paleo-Asopos river, the period before the 7,000 BP, must have been directed to the submarine fan 6 , which is developed between the isobaths of minus 35 and 45 meters. These depths must correspond to the former coastline during the period between 9,000 and 11,000 
years BP approximately, taking into consideration the various curves of the shoreline displacement as those given by Kraft et al (1985).

Furthermore, paleo-Asopos follows the paleo-valley that had once been formed between the islet Moni and Agistri Island. So paleo-Asopos was probably discharging into the paleo-gulf, which is formed between Aegina, the islet Moni and the southeast part of Methana peninsula, which we consider to be the Proto-Saronic. This is the area were the sea entered through in a period of time when the sea level had risen over the saddle between Agistri and Methana, causing the flooding of the Epidaurus Paleolake.

\section{Discussion - Conclusions}

From the former analysis, it seems that due to the morphotectonic evolution and the volcanic activity of the area between Troizinia, Agistri island and the Methana volcanic peninsula it has been shaped a submarine saddle at depths 70-75 meters approximately which forms a kind of natural barrier that isolates the morphological depression which has been formed in the area occupied by Epidaurus Paleolake.

Taking into consideration the paleogeographical evolution of the coastal areas and generally the area that today is occupied by the Saronic Gulf we believe that the characterization of Asopos as the progenitor of the islands Aegina and Salamis is directly connected with the route of the river during the period between 18,000 and 6,000 years BP. The reason must be connected with the fact that the prehistorical inhabitants of these period, from the period of time they had realized that the sea level begins rising gradually, shortly after 18,000 BP and mainly after 16,000 BP, obviously wanted to give an explanation about the phenomenon which disturbed their whole life. It is sure that they didn't have knowledge of the climatic eustatic movements. The inhabitants were observing that the river carried away, day by day, its waters into the sea. Therefore they believed that Asopos was responsible for the gradual sea level rise and the flooding of the area, which early humans exploited available resources such as preys, water springs, etc.

With the gradual rising of the sea level various islands were formed. That's why a river, in this case Asopos, could become a God and in the same time the progenitor of many islands and in this case Aegina and Salamis.

It's certain that many won't accept the suggested interpretation. Anyway for us, who have studied the paleogeographic evolution of the wider area, we think it is a logical or reasonable geomythological explanation.

\section{References}

Chappel, J. \& Shackleton, N., 1986. Oxygen isotopes and sea level. Nature, 324, pp. 137-140.

Dietrich, V., Gaitanakis, P., Mercolli, I. \& Oberhansli, R. 1991. Geological map of Greece, Aegina island, 1:25000. IGME - Foundation Vulkaninstitut Immanuel Friedlander.

Duff, D., 1993. Holme's Principles of Physical Geology. Chapman \& Hall, p.791.

Emiliani, C., 1971. The last interglacial: Paleotemperatures and Chronology. Science, 171, pp. 571-3.

Fairbridge, R.W., 1961. Eustatic changes in sea level. Physics and Chemistry of the Earth, 4, 99-185.

Jinsun JI, Nicole Petit-Maire \& Zhongwei Yan., 1993. The last 1000 Years climatic change in arid Asia and Africa. Global and Planetary Change, 7, pp. 203-210.

Kakridis, I., 1986. Greek Mythology. Ekdotiki Athinon Publications (in Greek).

Kraft, J.C., Aschenbrenner, S.E. \& Rapp, G.Jr., 1977. Palaeogeographic reconstructions of coastal Aegean archaeological sites. Science, 195, 941-947. 
Kraft, J. C., Belknap, D.F. \& Demarest, J.M., 1985. Geological studies of coastal change applied to archaeological settings. In: Archaeological Geology, Ed. G. RAPP and J.A.GIFFORD, Yale University Press.

Lambeck, K., 1996. Sea-level change and shore-line evolution in Aegean Greece since Upper Paleolithic time. Antiquity, 70, 588-611.

Likousis, V. \& Anagnostou, Ch., 1992. Sedimentological and paleogeographical evolution of Saronic Gulf and the end of Quaternary period. Bul. of the Geol. Soc. of Greece, Vol. XXVIII/1, 501-510, (in Greek).

Mariolakos, I., 1998. The geomythological geotope of Lerni Springs (Argolis, Greece). Geologica Balcanica, 28. 3-4, 101-108.

Mariolakos, I., 2002. The geo-environmental dimension of Greek mythology. Bull. of the Geol. Soc. of Greece, vol. XXXIV/6, 2065-2086 (in Greek).

Mariolakos, I. \& Stiros, S., 1987. Quaternary deformation of the Isthmus and Gulf of Corinthos (Greece). Geology, 15, 225-8.

Mariolakos, I., \& Theocharis, D., 2003. Asopos river and the creation of Aegina and Salamis Islands (Saronic Gulg, Greece). A geomythological approach. In: The Mediterranean World Environment and History (editor: Eric Fouache), Elsevier Publication, Paris 2003, p. 301-307

Milankovitch, M., 1941. Kanon der Erdbestrahlung und seine Anwendung auf dem Eiszeitenproblem. Royal Serbian Sciences, Spec. Publ. 132, Section of Mathematical and Natural Sciences, V. 33, Belgrade, $633 \mathrm{p}$.

Mörner, N.A., 1971. Eustatic changes during the last 20000 years and a method of separating the isostatic and eustatic factors in an uplifted area. Palaeogeography, Palaeoclimatology, Palaeoecology, 19, 63-65.

Mörner, N.A., 1976. Eustasy and geoid changes. Journal of Geology, v. 84, No 2,. 123-151.

Paepe, R. \& Mariolakos, I., 1984. Paleoclimatic reconstruction in Belgium and in Greece based on Quaternary lithostratigraphic sequences. Proc. E.C. Climatology Programe Symposium, Sophia Antipolis, France, 2-5 October 1984.

Paepe, R., 1986. Landscape changes in Greece as a result of changing climate during the quaternary. In: Desertification in Europe, Eds. R. FANTECHI and N. MARGARIS. D. RIEDEL Pub. Co.

Paepe, R. \& Overloop, v.E., 1989. River and soils cyclicities interfering with sea level changes. In: Greenhouse Effect, Sea Level and Drought, Eds.: R. PAEPE, et al., NATO ASI Series, Series C, V. 325, pp. 253-280.

Papanikolaou, D., Lykoysis, V., Chronis, G. \& Pavlakis, P., 1988. A comparative study of neotectonic basins across the Hellenic arc: the Messiniakos, Argolikos, Saronikos and Southern Evoikos Gulfs. Basin Research, 1, pp. 167-176.

Pausanias. Greek travel - Attica. Ekdotiki Athinon Publications, Athens 1999 (in Greek).

Philippson, A., 1892. Der Peloponnes. Berlin.

Pope, K. \& Van Andel, Tj. H., 1984. Late Quaternary alluviation's and soil formation in the southern Argolid: its history, causes and archaeological implications. Journal of Archaeological Science, 11, pp. 281-306.

Ranke-Graves, R. von, 1955. Griechische Mythologie. Quellen und Deutung, Rowolts Deutsche Enzyclopadie, B 2.

Rapp, G. \& Gifford, J.A., 1982. Troy. The Archaeological Geology. Supplementary Monograph 4, University of Cincinnati, Princeton University Press.

Roberts, N., 1989. The Holocene. An Environmental History. Basil Blackwell, Oxford.

Schwarz, L. M. \& Tziavos, CH., 1975. Sedimentary provinces of the Saronic Gulf system. Nature, 257, pp. 573-575.

Vita-Finzi, C., 1969. The Mediterranean Valleys. Cambridge University Press.

Zangger, E., 1991. Prehistoric Coastal Environments in Greece. The vanished Landscapes of Dimini Bay and Lake Lerna. J. Field A., 18, 1-15. 